\title{
TRANSANAL ENDOSCOPIC MICROSURGERY (TEM) IN THE TREATMENT OF POSTOPERATIVE COLORECTAL STENOSIS
}

\section{Microcirurgia endoscópica transanal (TEM) no tratamento de estenose colorretal pós-operatória}

\author{
Roberto da Silveira MORAES ${ }^{1}$, Gerhard BUESS ${ }^{2}$, João Henrique Felício de LIMA ${ }^{1}$, \\ Glauco Afonso MORGENSTERN ${ }^{1}$, Gustavo Justo SCHULZ ${ }^{1}$, \\ Antônio Carlos Ligocki CAMPOS ${ }^{1}$, Júlio Cezar Uili COELHO ${ }^{1}$.
}

ABCDDV/615

Maraes RS, Buess G, Lima JHF, Morgenstern GA, Schulz GJ, Campos ACL, Coelho JCU. Transanal endoscopic microsurgery (TEM) in the treatment of postoperative colorectal stenosis. ABCD Arq Bras Cir Dig 2008;21(3):147-9

ABSTRACT - Background - Strictures of low colorectal anastomosis are increasing by use the anastomotic stapler. There are many kinds of treatments like dilation, transanal rectotomy, and resection with linear or circular stapler. Other methods includes endoscopic knifes, absorbable sutures and laparotomy. The Transanal Endoscopic Microsurgery (TEM) has been used to treat postoperative anastomotic stenosis. Cases report - Three cases of anastomotic strictures after low colorectal anastomosis were treated with TEM with success in medium follow-up. They had a good postoperative evolution without recurrence of symptoms and stenosis. Conclusion - The new TEM surgical approach seems to be a safe choice for the treatment of the postoperative colorectal stenosis.

HEADINGS - Surgical procedures, minimally invasive. Postoperative Complications.

\section{INTRODUCTION}

Anastomotic strictures following colorectal or coloanal anastomosis is a current complication due to inadequate irrigation, anastomotic leakage and technique problems.

According to the literature, the incidence of anastomotic stenosis varies from 15 to $40 \%{ }^{2,5,9}$. Most of them are treated with digital dilation, bougie or proctoscope. Many others procedures have been used as transanal rectotomy with proctoscope, and transanal resection with a circular or linear stapler ${ }^{4,11}$. Endoscopic treatment using a pappilothome was already used in this circunstances ${ }^{1}$.

The partial resection of colorectal stenosis with TEM was first report in 1997 by Kato et al. ${ }^{7}$ using the contact Nd: YAG laser.

We report three cases of colorectal postoperative strictures treated successfully using transanal endoscopic microsurgery (TEM).

From the ${ }^{1}$ Department of Surgery, Hospital de Clínicas of Federal University of Paraná, Curitiba, PR, Brazil, and ${ }^{2}$ Department of General Surgery, Eberhard-Karls University, Tuebingen, Germany.

Correspondence: Roberto da Silveira Moraes, e-mail: rdsmoraes@ig.com.br

\section{CASES REPORT}

Case 1: A 64-year-old man was admitted with a postoperative colorectal anastomotic stenosis. Twenty four months prior to admission, the patient underwent to a low anterior resection to treat colonic Chagas' disease using an EEA stapling device. He had an anastomotic leakage with an spontaneous closure.

Rectoscopy showed a rectal stenosis by $8 \mathrm{~cm}$ from the dental line. Transanal rectotomy using the Park's technique was done with a partial success. Sixty days after this procedure, the patient returned with symptoms. New rectoscopy showed a re-stricture at the same site (Figure 1). TEM was proposed to the treatment of this stenosis. Using a $40 \mathrm{~mm}$ operating rectoscope and a stereoscopic optic with sixfold magnification, exact visualization of the rectal stricture could be achieved. The insertion of endoscopic materials, specially a bipolar multifunction combination instrument, allowed a precise excision of the stenotic ring along its circumference (Figure 2).

Follow up showed a satisfactory postoperative evolution without recurrence of anastomotic stricture.

Case 2: A 69-year-old man was submitted to sigmarectum resection to treat a rectal cancer. A low colorectal anastomosis with EEA stapler and ileostomy were made. Anastomotic leakage was identified and closed with nonoperative treatment. After three months, a stricture of 


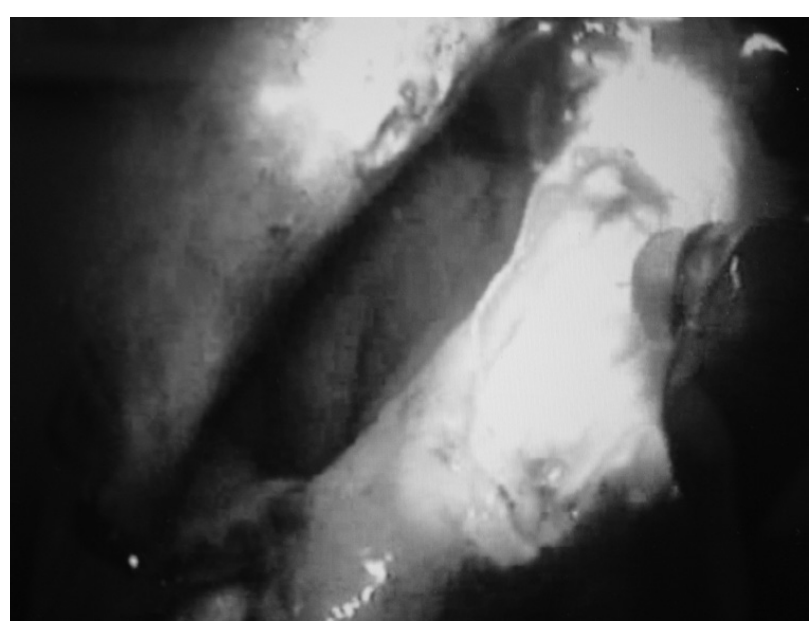

FIGURE 1 - Postoperative stricture after colorectal anastomosis

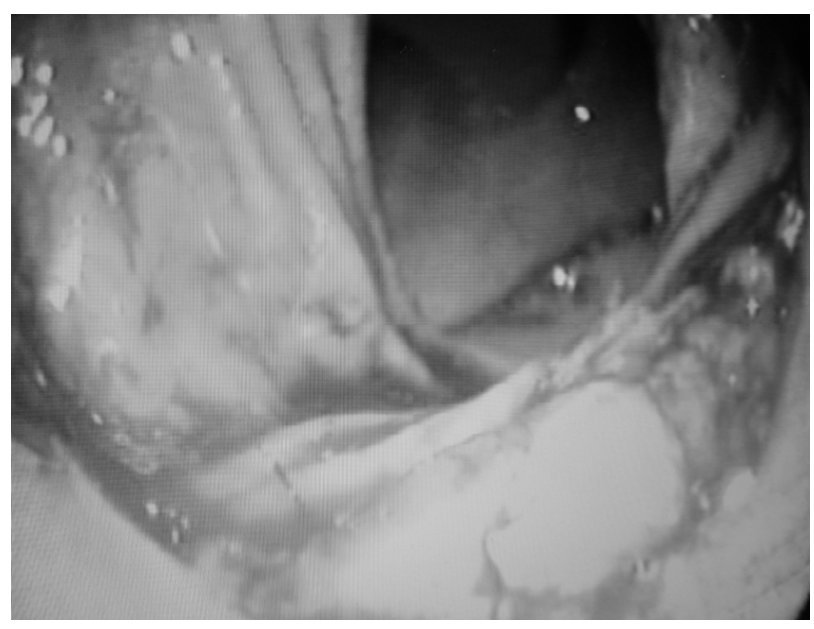

FIGURE 2 - Final anastomotic site view after TEM resection of the stenotic ring

anastomosis and a perineal fistula were detected. Transanal rectotomy with Park's technique was tried without success. Thirty days later, a new rectotomy was necessary. Six months after this procedure, he returned with the same symptoms. Rectoscopy showed the recurrence of the anastomotic stricture. Indication to the use of TEM was done in the same manner of the prior case with success. The resesction of stenotic ring was completed and the closure of the ileostomy was possible. He died one year late due to pulmonary metastasis.

Case 3: A 58-year-old woman with rectal cancer was submitted to low anterior resection with colorectal anas- tomosis using EEA stapler. Anastomotic total leakage was identified and a Hartmann's procedure was necessary. After four months, the digestive reconstruction was made. She had anastomotic leakage again, and non-operative treatment was tried with success. Stricture of anastomosis was detected one year later. Rectotomy with TEM technique was used and the stenotic ring was completed resected. She maintain a normal intestinal function in medium follow-up.

\section{DISCUSSION}

The use of staplers for colorectal anastomosis increases postoperative stenosis. Despite most of the times they are asymptomatic and easily treated, they have a high recurrence rate ${ }^{9}$. To deal this condition, Benoist et al. used absorbable suture around the stricture area after bougie dilation in 16 patients with satisfactory results ${ }^{2}$.

The EEA stapler can be used in these situations too. Lausten $^{8}$ and Rodrigues ${ }^{14}$ used an EEA stapling device in strictures after Hartmann's operation. Morrison Jr. and Jacobs reported two cases of anastomotic stricture widening with linear stapler ETS by transanal access ${ }^{13}$. Buhr et al. ${ }^{4}$ used an ELC 35 linear stapler in the same indication.

Transanal rectotomy have been used to treat low anastomotic stenosis. Hunt and Kelly treated an anastomotic stapler stricture with partial resection of stenotic ring using monopolar high frequency coagulation ${ }^{6}$. This transanal access is not so easy. Visualization and exposition are often inadequate. The difficulty increases proportionally the distance of the dental line. Consequently, significant failure of this treatment occurs.

TEM was introduced by Buess et al. ${ }^{3}$ to treat rectal cancer and became a good alternative method to treat also the postoperative anastomotic strictures. The stereoscopic optical device with magnification associate to special TEM instrumentals allowed an easy access and good vision of the stenotic area in the three cases. TEM reduced the difficulties and a success treatment was possible. However, this method should be done in reference centers with adequate equipment and trained team ${ }^{12}$.

\section{CONCLUSION}

The new TEM surgical approach seems to be a safe choice for the treatment of the postoperative colorectal stenosis. 
Maraes RS, Buess G, Lima JHF, Morgenstern GA, Schulz GJ, Campos ACL, Coelho JCU. Microcirurgia endoscópica transanal (TEM) no tratamento de estenose colorretal pós-operatória. ABCD Arq Bras Cir Dig 2008;21(3):147-9

RESUMO - Introdução - Estenoses de anastomoses colônicas baixas estão sendo mais relatadas devido ao maior uso de anastomoses mecânicas. Existem vários processos de tratamento como dilatações, retotomia transanal e ressecções com re-anastomoses mecânicas. Outros métodos incluem secções endoscópicas, secções com anastomoses com suturas absorvíveis e laparotomia. A Microcirurgia Endoscópica Transanal (TEM) está sendo proposta para o tratamento das estenoses anastomóticas. Relato dos casos - Três casos de estenoses anastomóticas foram tratados pela TEM com bom resultado em relação ao seguimento a médio prazo sem recurrência de sintomas. Conclusão - A TEM parece ser boa opção para o tratamento das estenoses resultantes das anastomoses coloretais baixas.

DESCRITORES - Procedimentos cirúrgicos minimamente invasivos. Complicações pós-operatórias.

\section{REFERÊNCIAS}

1. Accordi F, Sogno O, Carniato S, et al. Endoscopic treatment of stenosis folowwing stapler anastomosis. Dis Colon Rectum 1987; 30: 647-649.

2. Benoist S, Panis Y, Berdah S, Hautefeuille P, Valleur P. New treatment for ileal pouch-anal or coloanal anastomotic stenosis. Dis Colon Rectum 1998; 41: 935-937.

3. Buess G, Theiss R, Günther M, Hutterer F, Pichlmaier H. Transanal endoscopic microsurgery. Leber Magen Darm 1985; 15: 271-279.

4. Buhr J, Hürtgen M, Kelm C, Henneking K. Use of an endoscopic stapler for transanal widening of rectal anastomotic stenosis. Chirug 1995; 66: 428-430

5. Galandiuk S, Scott NA, Dozois R, et al. Ileal pouch-anal anastomosis: reoperation for pouch-related complications. Ann Surg 1990; 212: 446-452.

6. Hunt TM, Kelly MJ. Endoscopic transanal resection (ETAR) of colorectal strictures in stapled anastomosis. Ann R Coll Surg Engl 1994; 76: 121-122.

7. Kato K, Saito T, Matsuda M, et al. Successful treatment of a rectal anastomotic stenosis by transanal endoscopic microsurgery (TEM) using the contact Nd:YAG laser. Surg Endosc 1997; 11: 485-487.

8. Lausten SB, Sakso P. Treatment of stenotic colorectal anastomosis by transanal use of an endoscopic stapler. Br J Surg 1994; 81: 144
9. Lewis WG, Kuzu A, Sagar PM, Holdsworth PJ, Johnston D. Stricture at the pouch-anal anastomosis after restorative proctocolectomy, Dis Colon Rectum 1994; 37:120-125.

10. MacRae HM, McLeod RS. Handsewn vs. stapled anastomosis in colon and rectal surgery: a metanalysis. Dis Colon Rectum 1998; 41: 180-189.

11. Mclean Ross AH. Rectal stricture resection using the EEA autostapler. Br J Surg 1980; 67: 281-282.

12. Moraes RS, Buess G, Campos ACL, et al. Microcirurgia endoscópica transanal no tratamento do câncer superficial do reto: relato de caso. Arq Bras Cir Dis 2002; 15: 36-39.

13. Morrison Jr. JE, Jacobs VR. Laparoscopy-assisted endoscopic bowel anastomosis stenosis revision with stapler. Report of two cases. Surg Laparosc Endosc 1998; 8: 211-214.

14. Rodrigues LV, Regadas FSP, Leão PHS, et al. Re-anastomose retal sem laparotomia. Rev Bras Coloproct 2001; 21: 23-25.

Fonte de financiamento: não há Conflito de interesse: não há Recebido para publicação: 03/03/2008 Aceito para publicação: 30/06/2008 